\title{
Salinity and water clarity dictate seasonal variability in coastal submerged aquatic vegetation in subtropical estuarine environments
}

\author{
Eva R. Hillmann ${ }^{1}$, Kristin DeMarco ${ }^{1}$, Megan K. La Peyre ${ }^{2, *}$ \\ ${ }^{1}$ School of Renewable Natural Resources, Louisiana State University Agricultural Center, Baton Rouge, \\ Louisiana 70803, USA \\ ${ }^{2}$ U.S. Geological Survey, Louisiana Cooperative Fish and Wildlife Research Unit, School of Renewable Natural Resources, \\ Louisiana State University Agricultural Center, Baton Rouge, Louisiana 70803, USA
}

\begin{abstract}
Spatial and temporal variability characterize submerged aquatic vegetation (SAV) assemblages, but understanding the complex interactions of environmental drivers of SAV assemblages remains elusive. We documented SAV composition and biomass across a salinity gradient in a coastal estuary over 12 mo. Ten macrophyte species were identified. The dominant species, Ceratophyllum demersum and Myriophyllum spicatum, accounted for over $40 \%$ of total biomass. Only Ruppia maritima occurred across the salinity gradient. Salinity, water depth and clarity delineated 3 assemblages: a saline assemblage, and 2 groups of fresher-water species, one associated with deeper water and lower water clarity and the other associated with shallow water and higher water clarity. These assemblages exhibited intra-annual variation, with at least 5 times more biomass in late spring/mid-summer compared to early winter. This pattern was consistent across the estuary, although the difference between peak and low biomass varied by habitat type; brackish exhibited the greatest magnitude. This variation is likely due to higher variation in salinity and the species composition of this habitat. As climate change and coastal restoration impact timing and range of salinity, water depth and clarity in this region, these data can be used to help inform predictive models and management decisions.
\end{abstract}

KEY WORDS: Submerged aquatic vegetation $\cdot$ SAV $\cdot$ Biomass $\cdot$ Root to shoot $\cdot$ Spatial $\cdot$ Temporal

\section{INTRODUCTION}

Spatial and temporal environmental variation control species distributions and abundances by defining habitat conditions that structure vegetation communities (Weiher \& Keddy 1995, Wiens 2000). Describing this variation across multiple scales and identifying factors that control change remains a critical challenge for predicting vegetation communities and resulting habitat changes (Horne \& Schneider 1995). Extensive research to understand drivers of habitat change and variation in terrestrial systems (Pickett \& Cadenasso 1995) has expanded to include aquatic ecosystems (Harrison 1982, Chrysoula \& Papaster-

\footnotetext{
*Corresponding author: mlapeyre@agcenter.lsu.edu
}

giadou 2007). Understanding the relative influence of different factors structuring these aquatic communities remains critical to informing coastal management and restoration by enabling more accurate modeling and predictions of changing submerged aquatic vegetation (SAV) with climate change and coastal restoration.

Within coastal aquatic systems, highly productive shallow water habitats are influenced by the confluence of terrestrial and marine forces which control water characteristics, including salinity, turbidity, light and nutrients. The relative influence of terrestrial and marine factors establishes gradients, which define habitats and drive species assemblages. These

(c) E. R. Hillmann, K. DeMarco and outside the USA, the US Government 2019. Open Access under Creative Commons by Attribution Licence. Use, distribution and reproduction are unrestricted. Authors and original publication must be credited. 
gradients vary across and between estuaries, and inter- and intra-annually in response to landscape variation, climatic cycles, disturbance and management. Along estuarine environmental gradients, SAV distribution and biomass vary spatially and temporally, responding rapidly to changing water salinity, light and nutrient conditions resulting from precipitation, storm events and human activities (Frankovich et al. 2011, Correia et al. 2012, DeMarco et al. 2018, Patrick et al. 2018). The resulting temporal and spatial variation in the environment determine the composition of SAV assemblages through direct and indirect impacts on species survival, reproduction and growth rates, ultimately defining the distribution, abundance and composition of the community (Fourqurean et al. 2001, Patrick et al. 2018).

In southern Louisiana, USA, shallow water areas extending across the salinity gradient remain largely controlled by freshwater inputs from precipitation, large rivers and wind and storm events (Bianchi \& Allison 2009). Within these areas, SAV species serve as foundation species, yet assemblages, biomass and controls on patterns of intra-annual variation of SAV along this estuarine gradient have not been thoroughly described. In general, greater species diversity and biomass are observed during summer months, with declines in winter months (Dunton 1994, Cho \& Poirrier 2005a), while fresher SAV assemblages tend to have higher diversity and biomass compared to brackish and saline assemblages (Chabreck 1972, Cho \& Biber 2016). Across the northern Gulf of Mexico, a 2 yr survey documented 14 species of SAV across the estuarine gradient, with up to 11 species occurring within each salinity zone, but significantly greater biomass within the fresher assemblages (Hillmann et al. 2016). However, within Louisiana, the few studies of SAV intra-annual variation have mostly been limited to 1 salinity area (brackish), and provide conflicting reports, with 1 study reporting 2 peaks of SAV biomass in Ruppia maritima-dominated assemblages (Joanen \& Glasgow 1965), and 1 study finding no seasonal pattern of SAV abundance (Merino et al. 2005).

Temporal and spatial variation in SAV assemblages across the salinity gradient likely reflect multiple and co-varying environmental controls. For example, salinity and light availability are often identified as 2 critical controls on individual species and SAV presence (Koch 2001, Cho \& Biber 2016, DeMarco et al. 2018). However, past studies in Louisiana have reported general trends of deeper waters in upstream freshwater areas of the estuary, as compared to more down-stream saline areas (i.e. Penfound \& Hathaway 1938, Snedden \& Steyer
2013). How this trend in water depths affects light attenuation across the estuarine gradient is also related to water turbidity, which may depend on soil types, riverine inflows and solar radiation patterns throughout the year. Similarly, sediment anoxia drives sulfide accumulation, which tends to be associated with higher salinity habitats; in emergent marshes, this reduces the number of species able to adapt, decreasing species diversity (Howarth \& Teal 1979). Lastly, the more down-estuary saline habitats tend to be areas with greater fetch, as opposed to the small interior ponds typical of the fresher habitats; this resulting landscape exposes these more saline areas to increasing wave action and turbulence, which can limit SAV distributions and impact species assemblages (Koch 2001, DeMarco et al. 2018).

The coast of southeast Louisiana is rapidly changing, likely with shifting environmental resources, including SAV. Therefore, the main objective of this study was to examine intra-annual variation in SAV biomass and assemblages across a salinity gradient. Specifically, the goals were to (1) examine intraannual trends in SAV biomass, and (2) compare SAV biomass and species assemblages across the estuarine gradient. Using Barataria Basin, Louisiana, as our study area, we hypothesized that (1) SAV exhibits intra-annual variation; (2) SAV biomass and species number will be negatively associated with increasing salinity; and (3) species assemblages are unique across the salinity gradient, and can be delineated into 4 groups (fresh, intermediate, brackish, saline) based predominantly on salinity zonation of emergent marsh vegetation (Visser et al. 2013). Identifying the drivers of intra-annual SAV variability across the estuarine gradient, especially within rapidly changing coastal areas such as southeastern Louisiana, will enable more accurate modeling and predictions of changing SAV with climate change and coastal restoration.

\section{MATERIALS AND METHODS}

\subsection{Study area and sampling design}

This study took place within an estuary located within the Louisiana coastal plain in southeast Louisiana from February to December 2015. Calendar year 2015 was representative of recent years in terms of average high $\left(26^{\circ} \mathrm{C}\right)$ and average low $\left(18^{\circ} \mathrm{C}\right)$ temperatures, was within the normal range $(0-12$ d) of days below freezing $(2015=3$ d), but ended on the high end of annual precipitation 


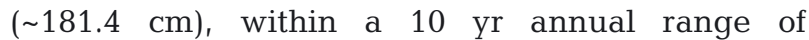
$136.9-183.9 \mathrm{~cm}$ (NOAA 2019). The Louisiana coastal plain supports one of the largest areas of coastal wetlands in the USA, but has lost approximately $4877 \mathrm{~km}^{2}$ of land since the 1930 s due to management of the Mississippi River, oil and gas canals, subsidence, sea-level rise and tropical storms (Peyronnin et al. 2013). For the study, we examined sites within Barataria Basin, Louisiana. This basin encompasses approximately $1214 \mathrm{~km}^{2}$, and is bordered on the north and east by the Mississippi River, on the west by Bayou Lafourche and on the south by the Gulf of Mexico. Barataria Basin consists of a mosaic of diverse estuarine habitat types: forested swamps, fresh through saline marshes, extensive shallowwater habitats with sediment bottoms, oyster reefs, SAV and floating aquatic vegetation habitats and barrier islands.

Within Barataria Basin, 16 study sites stratified across 4 salinity zones, defined by marsh habitat type (fresh, intermediate, brackish, saline; Visser et al. 2013) were selected (Fig. 1). Sites were randomly located within the designated habitats, in shallow water areas of potential SAV habitat (Hillmann et al. 2016), and located within $1 \mathrm{~km}$ of a coast-wide reference monitoring station (CRMS) (http://lacoast. gov/crms2/home.aspx). CRMS provide continuous water quality data (salinity, temperature $\left[{ }^{\circ} \mathrm{C}\right]$, water level [m]). If a randomly assigned site failed to land on an existing SAV bed, the site was moved (just on the initial site visit) to an existing SAV bed within the vicinity. Thereafter, the site was located at the new location and tracked over time, regardless of SAV presence. Within each habitat type, 4 sites were selected and sampled in triplicate approximately bi-monthly (February, April, May, July, August, October, December) through most of 2015 (4 habitat types $\times 4$ sites $=16$ total sample sites $\times 3$ subsamples (replicates) per site $\times 7$ dates $=$ 336 samples).

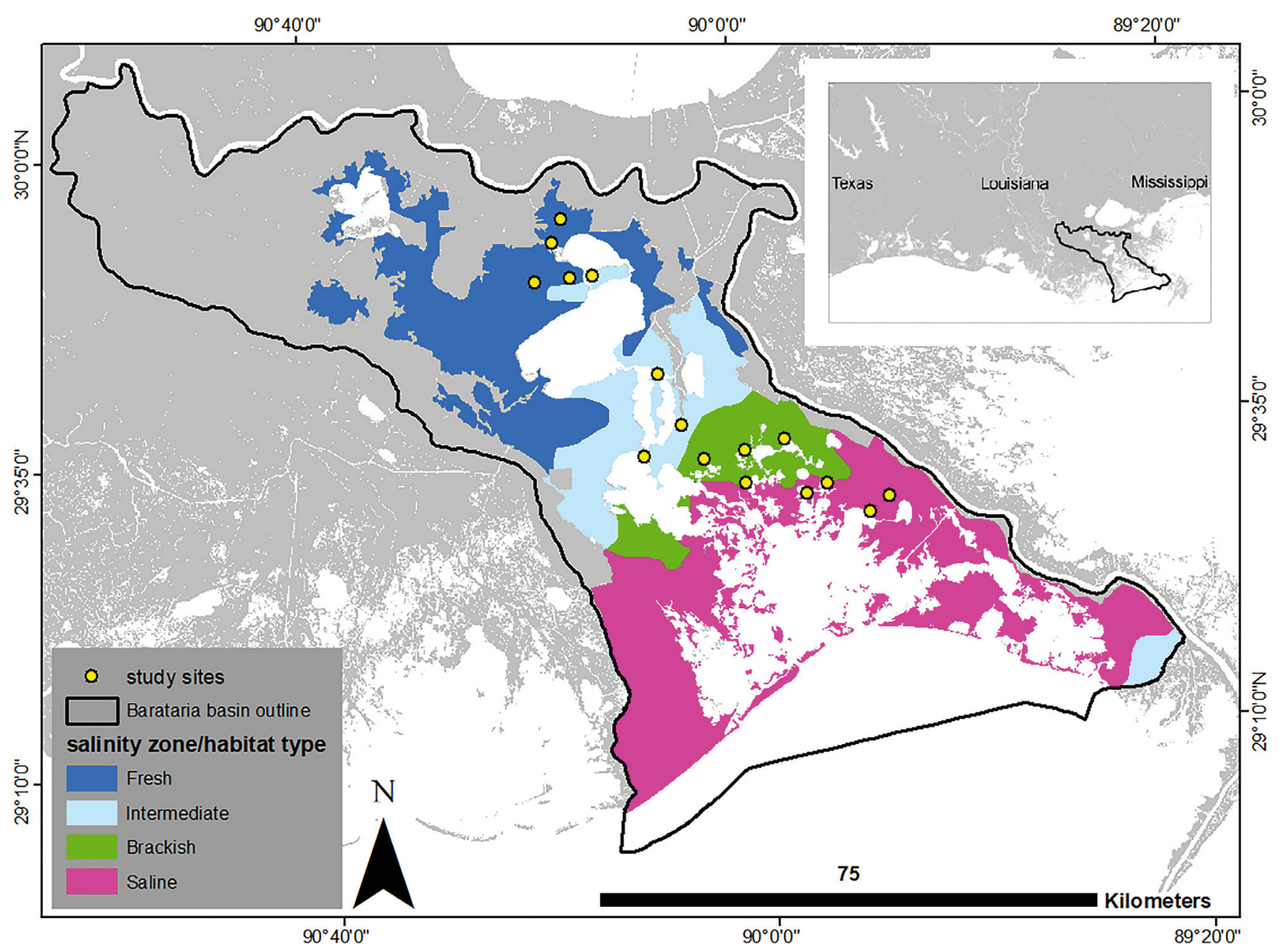

Fig. 1. Location of study sites distributed across Barataria Basin, Louisiana, USA. Inset (upper right) shows the location of Barataria Basin along the northern Gulf of Mexico, USA 


\subsection{Field data collection}

Sites were accessed and sampled from boats. Upon arrival at each site, water salinity and temperature $\left({ }^{\circ} \mathrm{C}\right.$; measured with a YSI-85, YSI), photosynthetically active radiation (PAR, $\mu \mathrm{mol} \mathrm{m} \mathrm{m}^{-2} \mathrm{~s}^{-1}$; measured with an LI-1400, LI-COR), dissolved oxygen (DO, $\mathrm{mg} \mathrm{l}^{-1}$; YSI-85, YSI), pH (Hach Pocket Pro+) and turbidity (in nephelometric turbidity units [NTU]; Hach 2100Q) were sampled approximately $0.25 \mathrm{~m}$ above bottom sediments. After recording water characteristics, SAV was sampled by throwing a $0.25 \mathrm{~m} \times 0.25 \mathrm{~m}$ floating PVC quadrat haphazardly 3 times from the boat. Within each quadrat, water depth was measured using a metric measuring stick $( \pm 0.01 \mathrm{~m})$, and SAV presence/absence was recorded. When SAV was present, all aboveground (AG) biomass within the quadrat was harvested down to the sediment surface. Belowground biomass (BG) was collected at each site by coring 3 times to a depth of $30 \mathrm{~cm}$ just outside each replicate quadrat using a $10 \mathrm{~cm}$ diameter PVC corer with plunger. Any AG biomass attached to BG cores was removed in the field. All AG and BG samples were placed in individually labeled plastic bags, kept on ice and transported to the laboratory at the Louisiana State University Agricultural Center, where samples were stored at $4^{\circ} \mathrm{C}$ until processing. In February 2015 only, 1 soil core was collected at each site and used for determination of bulk density $\left(\mathrm{BD} ; \mathrm{g} \mathrm{cm}^{-3}\right)$ and organic matter $\left(\mathrm{OM}_{\text {; }}\right.$ $\%)$. A $5 \mathrm{~cm}$ diameter PVC corer with a plunger was pushed into the soil to a depth of $20 \mathrm{~cm}$. Extracted cores were placed into individually labeled plastic bags, stored on ice and transported to the laboratory for processing.

\subsection{Laboratory processing and calculations}

AG biomass samples were washed to remove sediment, debris and epiphytic material, and biomass was then separated by live and dead tissue to species level. Separated AG samples were dried at $60^{\circ} \mathrm{C}$ to a constant weight, and weight was recorded $( \pm 0.001 \mathrm{~g})$. Species-specific live AG biomass values were obtained per site by averaging species subsample values. The total live AG biomass values for each site were calculated by summing all species-specific live AG biomass values per subsamples, and then obtaining a mean $( \pm \mathrm{SE})$ value for each site. BG samples were rinsed on a $1.4 \mathrm{~mm}$ mesh screen to remove sediment and debris. Samples were separated into live and dead roots, dried at $60^{\circ} \mathrm{C}$ to a constant weight, and weight was recorded $( \pm 0.001 \mathrm{~g})$. BG could not be separated to species level. Mean live BG biomass values $( \pm \mathrm{SE})$ were calculated by averaging live $\mathrm{BG}$ subsamples by site. Live AG biomass and live BG biomass values were summed by site to obtain total biomass values per site. The root to shoot ratio (RSR) was determined by dividing the dry weight of live AG biomass by the dry weight of total live BG biomass. To examine variation in total live biomass across habitats, the ratio of maximum to minimum biomass was calculated for each habitat type by averaging biomass in July and December by habitat type, and then dividing the mean of July by December.

Soil cores $(\mathrm{n}=16)$ were dried at $60^{\circ} \mathrm{C}$ to a constant weight. Dry weight was recorded $( \pm 0.001 \mathrm{~g})$ and used to calculate BD by dividing dry weight by the volume of the core. After drying and weighing, cores were homogenized using a mortar and pestle. To determine percent $\mathrm{OM}$, triplicate $4.0 \mathrm{~g}$ subsamples of each core were weighed out and burned at $550^{\circ} \mathrm{C}$ for $4 \mathrm{~h}$ using the loss on ignition method (Heiri et al. 2001).

\subsection{Analysis}

Differences in environmental variables (salinity, water depth, PAR, DO, $\mathrm{pH}$, turbidity, temperature) were tested across salinity zone (habitat) and sample date (month) using a repeated measure generalized linear mixed model with a Gaussian distribution and identity link function (Proc Glimmix, SAS Institute 2010). Soil properties (BD, OM) were tested using the same model, but with only habitat as a factor. We examined the independent and interactive effects of month (February, April, May, July, August, October, December) and habitat (fresh, intermediate, brackish, saline) on the independent environmental variables. The residual effect was the repeated measure of sampling the same site 7 times throughout the year. AG live biomass, BG live biomass and RSR were $\log _{10}(x+1)$ transformed and analyzed using the same model as for environmental variables. For all tests, a significance level of $\alpha=0.05$ was used. Unless indicated differently, mean \pm SE is reported. Tukey's HSD tests were run when significant differences were found.

For examination of SAV assemblage-environment relationships, canonical correlation analysis (CCA) with backward selection was performed with CANOCO software (ver. 4.5; ter Braak \& Smilauer 2002) to analyze the relationship between SAV assemblages (species-specific biomass) and environmental variables 
Table 1. Results of repeated measure generalized linear mixed model by habitat, month and habitat $\times$ month for salinity, temperature $\left({ }^{\circ} \mathrm{C}\right)$, dissolved oxygen $\left(\mathrm{DO}_{;} \mathrm{mg} \mathrm{l}^{-1}\right), \mathrm{pH}$, water depth $(\mathrm{m})$, photosynthetically active radiation $\left(\mathrm{PAR}, \mu \mathrm{mol} \mathrm{m}^{-2} \mathrm{~s}^{-1}\right)$ and turbidity (NTU). ${ }^{*} \mathrm{p}<0.05,{ }^{* *} \mathrm{p}<0.01,{ }^{* * *} \mathrm{p}<0.0001$

\begin{tabular}{|c|c|c|c|c|c|c|c|c|}
\hline & df & $\begin{array}{c}\text { Salinity } \\
F\end{array}$ & $\begin{array}{c}\text { Temp. } \\
\quad F\end{array}$ & $\begin{array}{c}\text { DO } \\
F\end{array}$ & $\begin{array}{c}\mathrm{pH}^{+} \\
F\end{array}$ & $\begin{array}{c}\text { Depth } \\
\qquad F\end{array}$ & $\begin{array}{c}\text { PAR } \\
F\end{array}$ & $\begin{array}{c}\text { Turbidity } \\
F\end{array}$ \\
\hline Habitat & 3,113 & $26.75^{* * *}$ & $7.07^{* *}$ & $8.36^{* *}$ & $6.42^{* *}$ & $3.76^{*}$ & $8.76^{* *}$ & 0.11 \\
\hline Month & 6,110 & $50.84^{* * *}$ & $118.42^{* * *}$ & $16.89^{* * *}$ & $9.05^{* * *}$ & $15.22^{* * *}$ & $3.05^{*}$ & $3.27^{* *}$ \\
\hline Habitat $\times$ Month & 18,99 & $8.24^{* * *}$ & $2.52^{*}$ & $2.87^{* *}$ & $3.24^{* *}$ & $2.35^{*}$ & 0.73 & 1.28 \\
\hline
\end{tabular}

(salinity, turbidity, PAR, DO, pH, water depth) separately for summer (July) and winter (December) samples. Species-specific biomass was $\log _{10}(x+1)$ transformed for the CCA to improve normality, and rare species were down-weighted. A Monte Carlo simulation test was used to determine statistical significance of canonical axes with 1000 simulations on the full model.

\section{RESULTS}

\subsection{Water and soil characteristics}

Salinity, water temperature, DO, $\mathrm{pH}$ and water depth differed significantly by the interaction of habitat and month (Tables 1 \& 2). Salinity was lowest at fresh SAV sites and did not vary significantly throughout the year (month), while other habitats had higher salinities, with distinct seasonal patterns marked by higher winter salinities and lower summer salinities (Fig. 2). Water temperature followed an expected annual trend, with lower temperatures in winter compared to summer months, and was lower at fresh sites compared to brackish and saline sites (Table 2). Water depth was significantly greater in the fresh habitat compared to saline habitat, but neither differed from intermediate or brackish habitat. Water depth was lowest in February $(0.36 \pm 0.04 \mathrm{~m})$ compared to all other months, which did not differ from one another. DO was significantly lower in fresh habitat compared to intermediate, brackish and saline habitats, which did not differ from one another. DO was significantly lower in May $\left(4.3 \pm 0.6 \mathrm{mg} \mathrm{l}^{-1}\right)$ than in February $\left(8.7 \pm 0.8 \mathrm{mg} \mathrm{l}^{-1}\right)$. $\mathrm{pH}$ was significantly lower in the fresh habitat compared to brackish and saline, and lowest in May $\left(6.7 \pm 0.3 \mathrm{H}^{+}\right)$as compared to October $\left(8.2 \pm 0.1 \mathrm{H}^{+}\right)$.

PAR and turbidity differed by single effects only (Table 1). Specifically, PAR differed significantly by habitat, with significantly higher values in saline habitat compared to fresh, intermediate and brackish habitats, which did not differ from one another. PAR was significantly greater in February (826.9 \pm 226.4 $\left.\mu \mathrm{mol} \mathrm{m} \mathrm{m}^{-2} \mathrm{~s}^{-1}\right)$ compared to December $(117.0 \pm 48.3$ $\mu \mathrm{mol} \mathrm{m} \mathrm{m}^{-2} \mathrm{~s}^{-1}$ ). Turbidity differed significantly only by month, with turbidity significantly higher in February and April than in May.

Soil OM and BD were similar across all habitat types. Mean OM was $36.2 \pm 4.9 \%$, and mean BD was $0.3 \pm 0.1 \mathrm{~g} \mathrm{~cm}^{-3}$.

Table 2. Mean $( \pm \mathrm{SE})$ and range of environmental properties and soil properties by habitat. DO: dissolved oxygen, PAR: photosynthetically active radiation

\begin{tabular}{|c|c|c|c|c|}
\hline & Fresh & Intermediate & Brackish & Saline \\
\hline \multicolumn{5}{|l|}{ Water quality } \\
\hline Salinity & $\begin{array}{c}0.2 \pm 0.1 \\
0.1-0.8\end{array}$ & $\begin{array}{c}0.6 \pm 0.6 \\
0.1-1.9\end{array}$ & $\begin{array}{l}4.9 \pm 3.1 \\
0.7-12.5\end{array}$ & $\begin{array}{l}9.4 \pm 4.2 \\
3.3-16.4\end{array}$ \\
\hline $\begin{array}{l}\text { Temperature } \\
\left({ }^{\circ} \mathrm{C}\right)\end{array}$ & $\begin{array}{l}23.1 \pm 1.1 \\
12.7-30.3\end{array}$ & $\begin{array}{l}25.1 \pm 1.0 \\
10.6-34.4\end{array}$ & $\begin{array}{c}26.4 \pm 0.95 \\
13.4-33.6\end{array}$ & $\begin{array}{c}26.4 \pm 0.95 \\
15.6-33.9\end{array}$ \\
\hline $\mathrm{DO}\left(\mathrm{mg} \mathrm{l}^{-1}\right)$ & $\begin{array}{c}4.0 \pm 2.5 \\
0.3-8.3\end{array}$ & $\begin{array}{l}7.1 \pm 3.5 \\
1.1-16.0\end{array}$ & $\begin{array}{l}7.7 \pm 7.7 \\
2.5-10.7\end{array}$ & $\begin{array}{l}7.1 \pm 2.4 \\
3.1-11.8\end{array}$ \\
\hline $\mathrm{pH}^{+}$ & $\begin{array}{c}6.9 \pm 0.7 \\
5.0-7.9\end{array}$ & $\begin{array}{c}7.5 \pm 1.2 \\
4.9-9.7\end{array}$ & $\begin{array}{c}7.8 \pm 0.8 \\
5.6-8.9\end{array}$ & $\begin{array}{c}7.6 \pm 0.6 \\
6.6-8.6\end{array}$ \\
\hline \multicolumn{5}{|l|}{ Water clarity } \\
\hline $\begin{array}{l}\text { Water depth } \\
\text { (m) }\end{array}$ & $\begin{array}{c}0.7 \pm 0.3 \\
0.3-1.6\end{array}$ & $\begin{array}{c}0.5 \pm 0.2 \\
0.2-1.0\end{array}$ & $\begin{array}{c}0.5 \pm 0.2 \\
0.2-1.0\end{array}$ & $\begin{array}{c}0.4 \pm 0.2 \\
0.1-1.0\end{array}$ \\
\hline $\begin{array}{l}\text { PAR } \\
\qquad\left(\mu \mathrm{mol} \mathrm{m}{ }^{-2} \mathrm{~s}^{-1}\right)\end{array}$ & $\begin{array}{c}271.1 \pm 400.4 \\
0.02-1316.8\end{array}$ & $\begin{array}{c}285.9 \pm 286.5 \\
9.49-1073.0\end{array}$ & $\begin{array}{c}299.7 \pm 275.8 \\
2.52-992.6\end{array}$ & $\begin{array}{c}649.9 \pm 455.6 \\
44.8-1514.7\end{array}$ \\
\hline $\begin{array}{l}\text { Turbidity } \\
\text { (NTU) }\end{array}$ & $\begin{array}{c}35.3 \pm 36.7 \\
1.4-111.0\end{array}$ & $\begin{array}{c}32.2 \pm 28.1 \\
4.8-126.0\end{array}$ & $\begin{array}{c}29.9 \pm 16.7 \\
11.0-96.7\end{array}$ & $\begin{array}{c}25.4 \pm 11.8 \\
23.9-56.0\end{array}$ \\
\hline \multicolumn{5}{|l|}{ Soil properties } \\
\hline $\begin{array}{l}\text { Organic matter } \\
(\%)\end{array}$ & $\begin{array}{c}34.2 \pm 13.6 \\
10.9-72.1\end{array}$ & $\begin{array}{c}47.7 \pm 13.5 \\
12.6-77.8\end{array}$ & $\begin{array}{l}28.5 \pm 2.1 \\
22.6-32.2\end{array}$ & $\begin{array}{c}34.4 \pm 7.4 \\
0.1-1.0\end{array}$ \\
\hline $\begin{array}{l}\text { Bulk density } \\
\left(\mathrm{g} \mathrm{cm}^{-3}\right)\end{array}$ & $\begin{array}{c}0.4 \pm 0.2 \\
0.1-0.7\end{array}$ & $\begin{array}{c}0.2 \pm 0.1 \\
0.1-0.5\end{array}$ & $\begin{array}{c}0.3 \pm 0.1 \\
0.3-0.4\end{array}$ & $\begin{array}{c}0.3 \pm 0.1 \\
0.2-0.3\end{array}$ \\
\hline
\end{tabular}




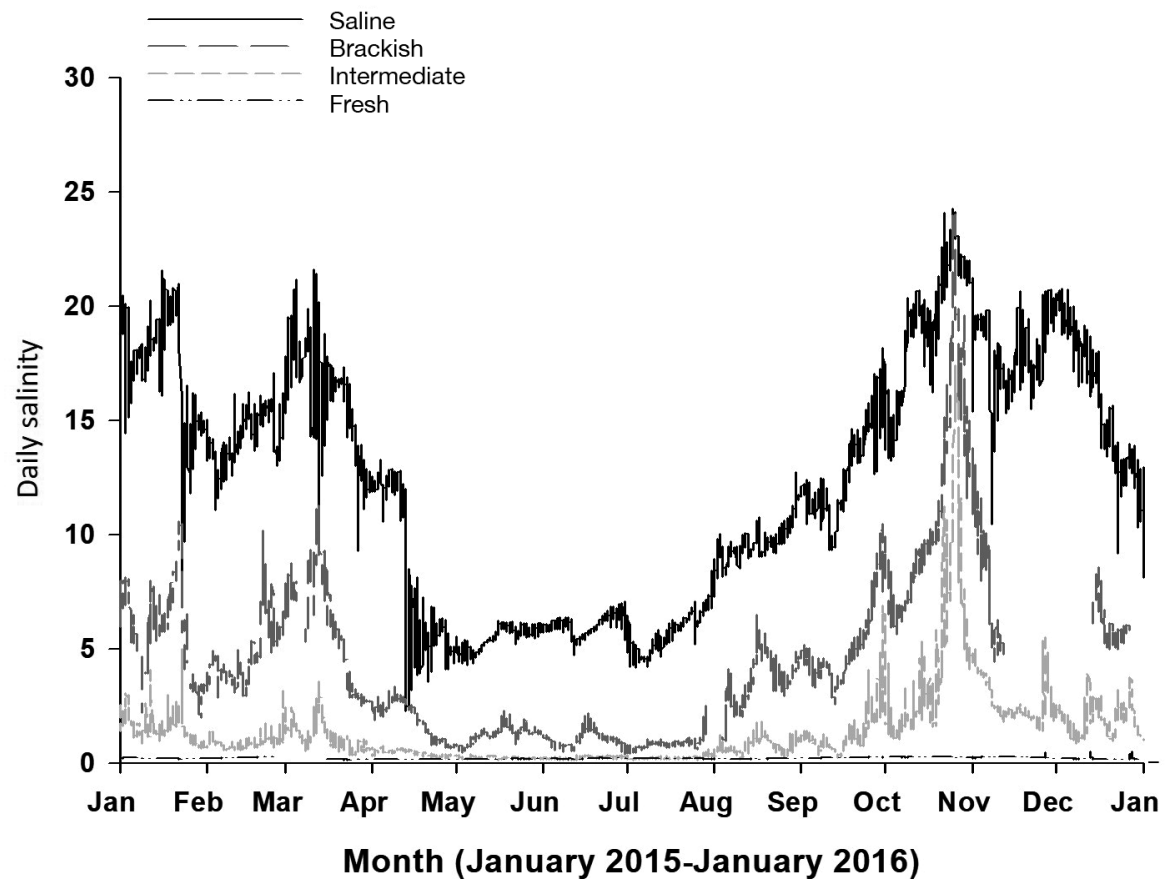

Fig. 2. Mean daily salinity recorded at Coastwide Reference Monitoring Stations (CRMS) located within $1 \mathrm{~km}$ of the study sites. CRMS were grouped by habitat (fresh, intermediate, brackish, saline)

\subsection{SAV biomass}

SAV presence (biomass) was not observed at every site in every habitat type throughout the year.
Within each habitat type at least 1 site was found devoid of SAV at least once throughout the study year, although $85 \%$ of observations of no SAV occurred at either brackish or saline sites, but with no clear temporal trends. Total live biomass $(A G+B G)$ differed significantly by month $\left(F_{6,110}=3.03, \mathrm{p}=\right.$ $0.0104)$ and habitat $\left(F_{3,113}=9.07, \mathrm{p}\right.$ $=0.0020)$, but not their interaction (Fig. 3A,B). May and July biomass (May: $63.8 \pm 21.8 \mathrm{~g} \mathrm{~m}^{-2}$; July: 52.0 $\pm 21.6 \mathrm{~g} \mathrm{~m}^{-2}$ ) were significantly greater than December biomass $\left(5.2 \pm 2.9 \mathrm{~g} \mathrm{~m}^{-2}\right)$, and this pattern was similar across the salinity gradient. Fresh habitat $(90.1 \pm 19.8 \mathrm{~g}$ $\mathrm{m}^{-2}$ ) and intermediate habitat total live biomass $\left(60.5 \pm 13.8 \mathrm{~g} \mathrm{~m}^{-2}\right)$ were similar and significantly higher than brackish $(5.0 \pm 1.8 \mathrm{~g}$ $\mathrm{m}^{-2}$ ) and saline live biomass (6.0 \pm $3.2 \mathrm{~g} \mathrm{~m}^{-2}$ ), which also did not differ from one another. RSR did not differ by salinity zonation, month or their interaction (Fig. 4). The ratio of maximum:minimum biomass was highest in brackish habitat (880) compared to fresh (29), saline (18) and intermediate (5).
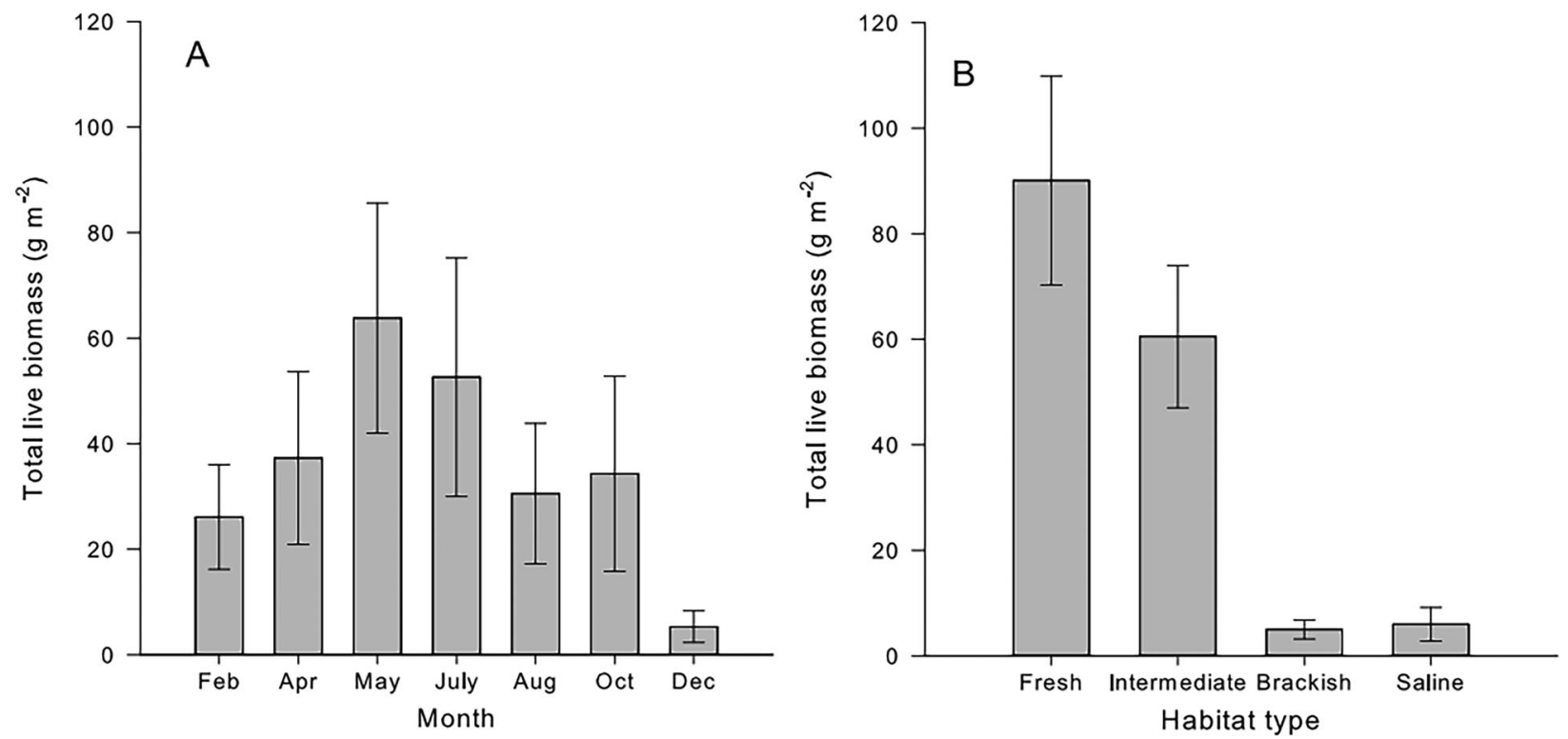

Fig. 3. Mean \pm SE total live biomass ( $\mathrm{g} \mathrm{m}^{-2}$; aboveground + belowground biomass) (A) by sampling month through 2015 , and (B) by habitat type. There were no significant interactions of habitat $\times$ month 


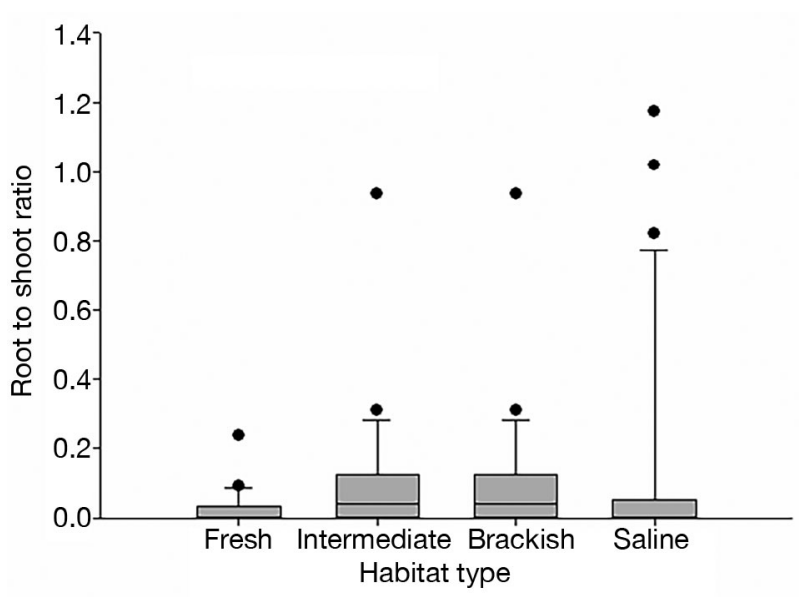

Fig. 4. Submerged aquatic vegetation root to shoot ratio by habitat presented as median, quartiles, minimum and maximum values and outliers. There were no significant differences by habitat or month

\subsection{SAV assemblages}

Ten species of SAV were identified across the estuarine gradient throughout the year (Table 3). Ceratophyllum demersum, Hydrilla verticillata, Najas guadalupensis and Myriophyllum spicatum were dominant among fresh and intermediate sites, while Ruppia maritima and M. spicatum were dominant at brackish and saline sites. The number of species differed only by habitat $\left(F_{1,115}=21.34, \mathrm{p}=0.0004\right)$. Fresh and intermediate sites contained more species (1.6 \pm $0.14)$ compared to brackish and saline sites (0.43 \pm 0.07; Table 3, Fig. 5). Fresh sites consisted of 7 species across the year, of which 3 represented over $98 \%$ of the total biomass (C. demersum, Cabomba caroliniana, $H$. verticillata). Intermediate sites supported 9 species, of which 3 represented $97 \%$ of the biomass (M. spicatum, N. guadalupensis, Vallisneria americana). Brackish sites only reported 4 species through- out the year, with 1 species (M. spicatum) accounting for $79 \%$ of total biomass. Saline sites only supported 1 species ( $R$. maritima) throughout the year.

\subsection{SAV-environment interactions}

Both the July and December CCA results divided the SAV species into 3 subgroups. The first 2 axes explain $79.3 \%$ (July) and $55.5 \%$ (Dec) of the variation between species (July: $F=6.23, \mathrm{p}=0.0020$; Fig. 6A, December: $F=15.237, p=0.0040$; Fig. 6B). In both cases, the first axis describes 48.2 and $29.8 \%$ (July and December, respectively) of the variation and largely differentiates between salt-tolerant and freshwater SAV species. Specifically, $R$. maritima is strongly associated with higher salinity and is distinct from freshwater SAV species. The second axis describes 37.7 and $25.7 \%$ (July and December, respectively) of the variation and differentiates between 2 groups of freshwater SAV species along an axis largely controlled by water depth and PAR. Specifically, the first group $(H$. verticillata, $C$. caroliniana), is associated with greater water depth, which largely describes freshwater communities located in the upper estuary. The second group ( $N$. guadalupensis, $M$. spicatum) is associated with higher PAR and shallower water depths, which are conditions often found throughout the middle intermediate to brackish regions of the basin.

\section{DISCUSSION}

Differences in salinity and water clarity (water depth, PAR, turbidity) defined SAV assemblages across the estuarine gradient, with high intra-annual

Table 3. Submerged aquatic vegetation biomass (mean $\pm \mathrm{SE}_{;} \mathrm{g} \mathrm{m}^{-2}$ ) by species across the estuarine gradient (fresh, intermediate, brackish, saline) in Barataria Basin, Louisiana, USA. No data are presented when species were not reported within a salinity zone

\begin{tabular}{|llccc|}
\hline Species & Common name & Fresh & Intermediate & Brackish \\
\hline Cabomba caroliniana & Carolina fanwort & $27.5 \pm 9.9$ & $0.1 \pm 0.1$ & \multirow{2}{*}{ Saline } \\
Ceratophyllum demersum & Coontail, hornwort & $32.5 \pm 8.0$ & $3.5 \pm 2.1$ & $0.1 \pm 0.04$ \\
Heteranthera dubia & Water stargrass & & $0.2 \pm 0.2$ & \\
Hydrilla verticillata & Waterthyme, hydrilla & $25.2 \pm 10.6$ & & $3.6 \pm 1.5$ \\
Myriophyllum spicatum & Eurasian watermilfoil & $1.7 \pm 1.2$ & $26.6 \pm 9.3$ & $0.07 \pm 0.07$ \\
Najas guadalupensis & Water nymph, najas & $0.002 \pm 0.002$ & $12.3 \pm 6.3$ & $0.9 \pm 0.4$ \\
Potamogeton pusillus & Lesser pondweed & $0.02 \pm 0.02$ & $0.01 \pm 0.01$ & $6.3 \pm 3.4$ \\
Ruppia maritima & Widgeongrass, ruppia & $0.3 \pm 0.3$ & $0.2 \pm 0.1$ & \\
Vallisneria americana & Eelgrass, wild celery & & $14.2 \pm 4.5$ & $0.07 \pm 0.07$ \\
Zannichellia palustris & Horned pondweed & & & \\
\hline
\end{tabular}



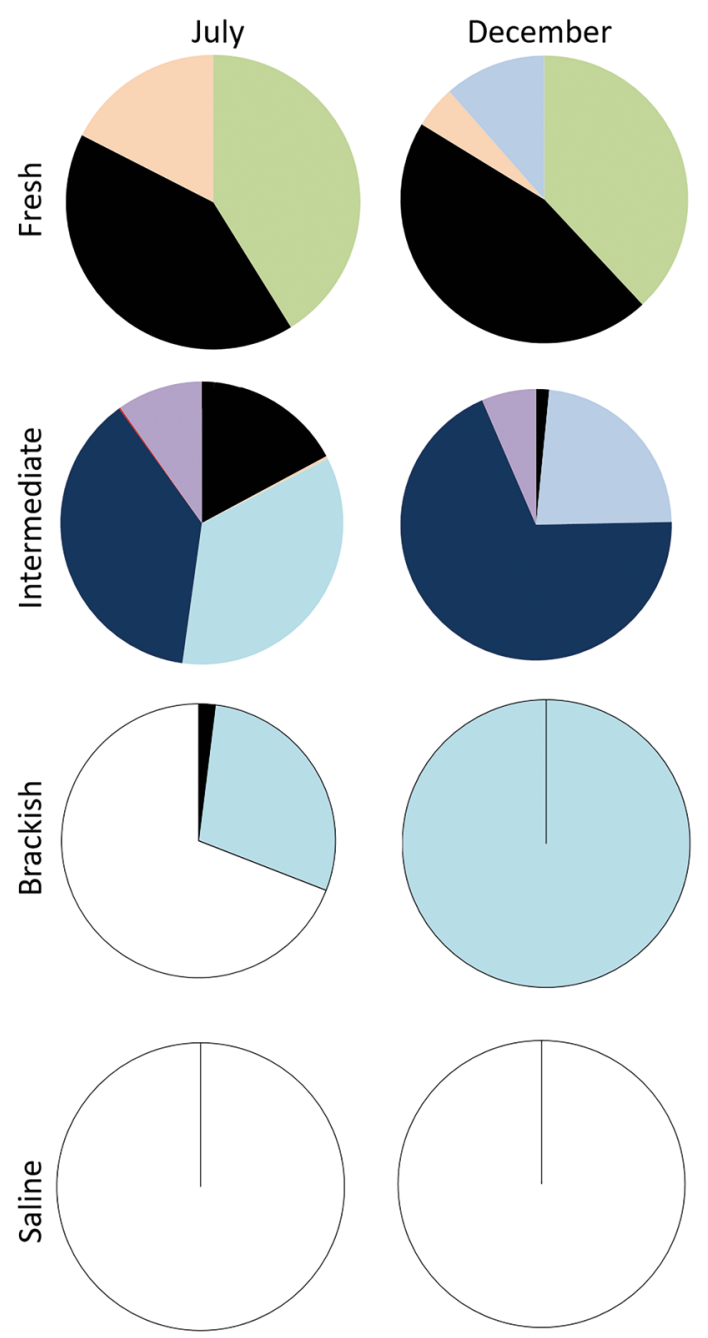

C. caroliniana

C. demersum

H. dubia

$H$. verticillata

M. spicatum

N. guadalupensis

R. maritima

V. americana

Fig. 5. Species assemblages based on species biomass $\left(\mathrm{g} \mathrm{m}^{-2}\right)$ in the 4 habitat types (fresh, intermediate, brackish, saline) in July and December (left and right columns, respectively), which reflect the minimum to maximum biomass values across salinity zones (habitat types). For all groups, the number of species and overall biomass decreased in December. Full species names are given in Table 3 variation. Across the estuarine gradient, intra-annual variation of biomass followed similar patterns with an early winter low (December), and a peak biomass in late spring to midsummer (May, July). However, the magnitude of biomass, diversity and species assemblages varied by habitat and water clarity (water depth, PAR, turbidity). Greater biomass and diversity occurred in fresh and intermediate environments, compared to brackish and saline. Furthermore, across all non-saline habitats, water clarity (depth, PAR, turbidity) distinguished 2 SAV assemblages with areas characterized by shallow water and increased PAR supporting a species assemblage distinct from areas characterized by deeper and lowerlight environments. The dynamic nature of SAV assemblages across the estuarine gradient suggests that species-specific responses to salinity and water clarity may be dominant drivers of SAV.

Strong intra-annual variation in SAV biomass occurred, with the highest biomass observed in late spring to mid-summer and the lowest in early winter; this pattern extended across
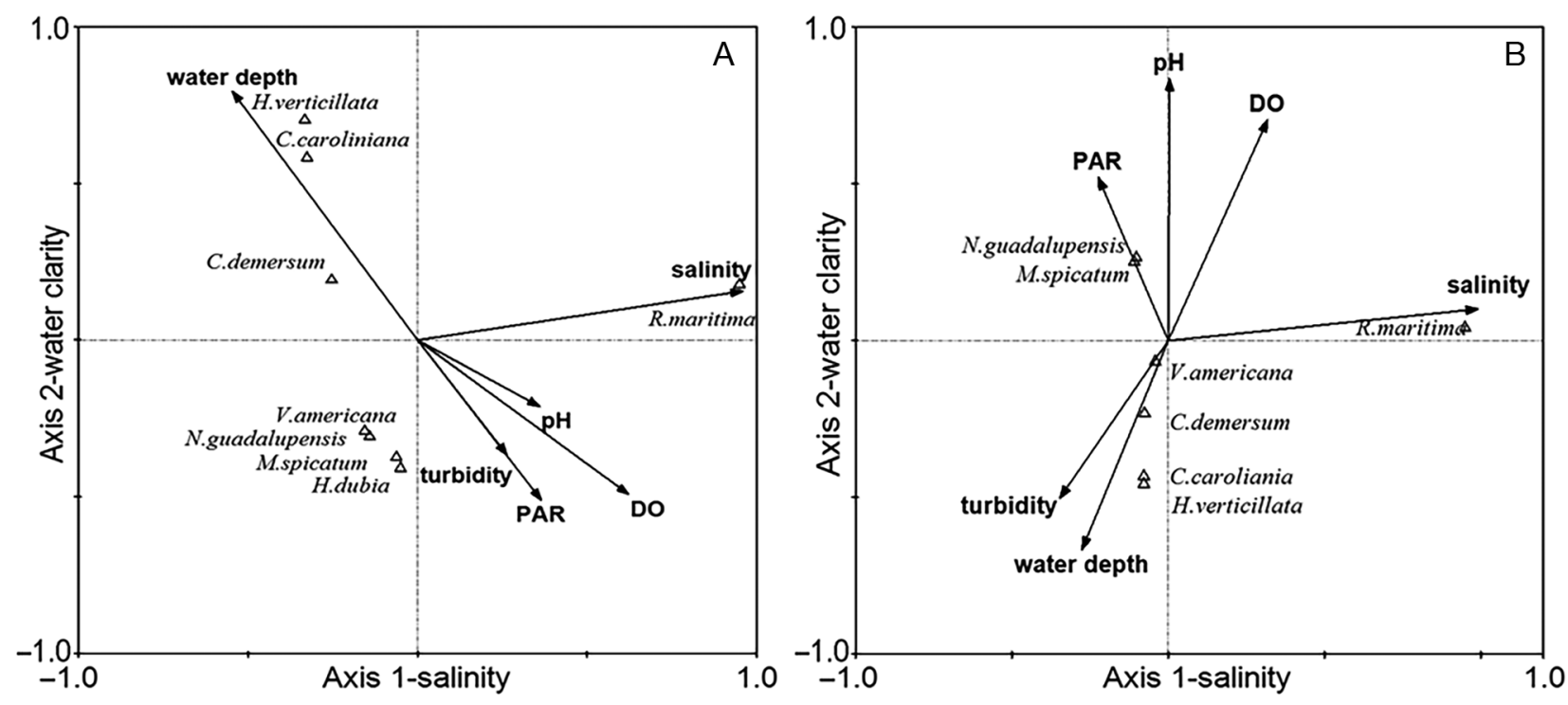

Fig. 6. Canonical correlation analysis of submerged aquatic vegetation species in relation to environmental variables (salinity, temperature, dissolved oxygen [DO], pH, water depth photosynthetically active radiation [PAR], turbidity) for (A) July and (B) December. Full species names are given in Table 3 
the estuary, although the magnitude of changes differed. The ratio of maximum:minimum biomass was high across all habitat types ( $\geq 5)$, with the brackish habitat having the highest ratio (880), followed by fresh (29), saline (18) and intermediate (5) habitats. This variation in ratios likely reflects the composition of species assemblages unique to each habitat type, combined with the variation of controlling factors. For instance, the extremely high ratio for brackish habitat may partially reflect the response of Myriophyllum spicatum (77\% standing stock), which has low tolerance for temperatures below $15^{\circ} \mathrm{C}$ (Smith \& Barko 1990). In coastal Louisiana, waters generally are below $15^{\circ} \mathrm{C}$ during winter months, and this resulted in a minimum of $0.01 \mathrm{~g} \mathrm{~m}^{-2}$ in the winter, relative to the mean high of $8.8 \mathrm{~g} \mathrm{~m}^{-2}$ in summer in brackish habitat. This high ratio may also reflect the high variability of salinity in the brackish habitat, with salinity above 10 multiple times, and a peak above 20 in late fall, which is thought to be lethal to M. spicatum (Gleason \& Cronquist 1991). Ultimately, however, brackish SAV biomass, in comparison to the other habitats along the estuarine gradient, supported, even at its max, relatively low biomass of SAV, suggesting that brackish SAV within this region may be particularly vulnerable to continued changes of temperature, salinity or other factors. Similarly, the maximum biomass in fresh areas reflects the growth with increasing temperatures in areas also dominated by light and temperature sensitive species (e.g. Hydrilla verticillata, Cabomba caroliniana, Ceratophyllum demersum $=98 \%$ fresh standing stock). $C$. demersum in particular increases biomass production at temperatures above $20^{\circ} \mathrm{C}$ (Wilkinson 1963). Although not examined in this study, biotic interactions may also be important in structuring these communities, likely having differential impacts across gradients of varying abiotic stress (i.e. Grime 1979). These findings, similar to patterns noted in other sub-tropical regions (i.e. Fourqurean et al. 2001, Cho \& Poirrier 2005a, Lirman et al. 2008), suggest the need to more fully examine SAV intraannual patterns within monitoring surveys to account for shifts in SAV assemblages and habitat availability throughout the year.

SAV intra-annual variation corresponded with variation in environmental conditions including salinity, water depth, water clarity and temperature. Salinity was the dominant factor driving species assemblages, biomass and species number, matching findings from past studies along the Gulf coast and in other regions (i.e. Carter et al. 2009, Borgnis \& Boyer 2016, Cho \& Biber 2016, Patrick et al. 2018). Overall,
SAV biomass and species number were consistently higher in the fresh and intermediate assemblages throughout the year. Fresh and intermediate assemblages were composed of up to 10 species, while brackish and saline assemblages were restricted to 2 consistently present species, similar to findings reported across other regions reporting up to 3 species in the higher salinity zones (Orth \& Moore 1988, Dunton 1990, Merino et al. 2009, Frankovich et al. 2011). For example, only 2 species, Ruppia maritima and Zostera marina are found in the saline areas of Chesapeake Bay (Patrick \& Weller 2015), and only 3 species (Halodule wrightii, Thalassia testudinum, Syringodium filiforme) dominate many saline lagoons in Texas, with only 1 species, $R$. maritima, reported in some saline Mexican lagoons (Flores-Verdugo et al. 1988, Dunton 1996). Interestingly, most of these reported studies come from saltier habitats $(>20)$ than Louisiana's saline zone; however, the overall number of species in these zones is similar, and the presence of $R$. maritima is a constant across most saline zones, including in estuarine habitats with variable salinity pulses.

Within highly variable estuarine environments, tolerance to salinity stress appears to limit the species assemblages as all but the fresh habitat experienced periods of salinity above 10 during the year. While 2 of the dominant fresh and intermediate assemblage species, M. spicatum and Vallisnaria americana, tolerate short exposures to salinities up to 15 (i.e. Gleason \& Cronquist 1991, Frazer et al. 2006), others, such as $H$. verticillata, only tolerate salinities as high as 5 for any period of time (Frazer et al. 2006). Both the fresh and intermediate sites had mean annual salinities below 5 in this study, although the intermediate sites were exposed to 2 short salinity pulses above 5 during the year. It is likely that the timing and length of these exposures may be important in structuring SAV assemblages. Although some studies examined the interactive effects of temperature and salinity pulses on species (Doering et al. 2001, La Peyre \& Rowe 2003, Frazer et al. 2006, Strazisar et al. 2015), few have looked at the interactive effects on species assemblages. The large maximum:minimum biomass ratios at intermediate sites could be reflecting the November pulse of salinity above 15 , which reduced the number of species present in July by close to $50 \%$. Similarly, confounding variables of sulfide toxicity (Howarth \& Teal 1979) and greater wave exposure (DeMarco et al. 2018) normally associated with higher salinity areas may also explain some of the differences in species assemblages along the salinity gradient and are not captured in this study. 
Within the fresher areas of the study, water depth and clarity further separated these non-saline SAV assemblages into 2 assemblages. Specifically, SAV growing in shallow and clear waters (Najas guadalupensis, V. americana, $M$. spicatum) formed distinct assemblages from SAV found in deeper and more turbid environments $(H$. verticillata, $C$. caroliniana). C. caroliniana and $H$. verticillata have adaptations that enable them to grow in deeper waters. For example, $H$. verticillata has been shown to survive in depths greater than $5 \mathrm{~m}$, due to its ability to grow long branching stems to reach the surface (Langeland 1996). In contrast, V. americana is generally found in waters of less than $0.3 \mathrm{~m}$ (Martin \& Uhler 1939). While water depth and light are important factors structuring SAV assemblages (i.e. Kemp et al. 2004, Cho \& Poirrier 2005b), comparisons among studies and regions are difficult, as water depth and water clarity are both used as proxies for light in some studies, while direct light measurements were recorded in others, which limits our ability to differentiate explicitly. In past SAV work, depth limits have been suggested to be related to light availability (i.e. Cho \& Poirrier 2005a,b). For seagrass, presence and growth have been suggested to occur to depths experiencing 8-25\% surface irradiance of light (i.e. Duarte 1991, Dennison 1993, Dunton 1994). Data from the present study found presence of SAV under conditions of $0.1-87.3 \%$ surface irradiance (mean $29.3 \pm 4.1 \%$ ), based on discrete sampling (Hillmann et al. 2017). Both the fact that our study explored SAV across an estuarine gradient with a range of species, and had only discrete data points, make relationships difficult to identify and suggest the need for more continuous data collections to better understand SAV habitat requirements.

Shifting biomass, abundance and composition of SAV assemblages results in concomitant changes in the ecological services SAV provide. For example, shifts from brackish or saline assemblages to more freshwater assemblages may influence resilience and shoreline protection services. Marine seagrasses often contain more biomass belowground than aboveground (Pulich 1985), with slender growth forms able to tolerate higher wave disturbance. SAV species farther up-estuary are morphologically more diverse, fragile and exhibit very sensitive growth patterns. Subsequently, freshwater SAV species may be more susceptible to exposure and storms, and possibly less effective at shoreline protection than their marine counterparts, although almost no studies exist to describe the effects of freshwater SAV on erosion. One of the most common species in the freshwater SAV habitats, C. demersum, contributed significantly to total SAV biomass, despite no real root system (Mishra et al. 2006). The pervasiveness of $C$. demersum throughout the basin may even partially explain the low RSR ( 0.1) compared to SAV and seagrass RSR elsewhere, which has been reported to range between 1 and 5 (Dunton 1996).

Coastal Louisiana, and Barataria Basin specifically, continue to experience rapid land changes, from subsidence and erosion (i.e. Couvillion et al. 2017). This land loss, combined with changing freshwater inputs from climate change (Keim et al. 2011), and ongoing and proposed coastal management activities (CPRA 2017) impact salinity, water depth and water clarity throughout the basin and the coast. Our results provide specific input to inform predictive models for the coast, and can be useful in informing habitat suitability models for species dependent on SAV habitats (i.e. CPRA 2017). Furthermore, how these changes combine with the timing and range of future minimum and maximum temperatures may be critical in understanding long-term SAV shifts. For instance, increasing temperature is expected over the next $100 \mathrm{yr}$, with the greatest increase expected to occur in the summer months (Keim et al. 2011). In southern Louisiana, where summer water temperatures already exceed $32^{\circ} \mathrm{C}$, understanding thermal tolerances of SAV species will be critical to inform models of SAV distribution. The timing and magnitude of changes may be important in predicting future SAV distributions, ultimately impacting habitat, refuge and food resource availability for dependent fish and wildlife species.

Acknowledgements. We thank multiple organizations and agencies who supported this research as part of a largescale effort to quantify coastal SAV resources in this region. For funding, we thank the US Geological Survey, South Central Climate Science Center, the Gulf Coast Joint Venture, the Gulf Coast Prairie Landscape Conservation Cooperative, and US Fish and Wildlife Service Region 2 and Region 4 through SSP funding. Many people were critical in helping to get this work done, including staff at state and national wildlife refuges, as well as all private landowners. Acknowledgement and gratitude go to Gary Peterson and numerous undergraduate student workers who put in many hours in the laboratory processing samples. Thanks to Dr. Erin Cox for comments on earlier versions of this manuscript, and to 3 anonymous reviewers for their constructive comments. Data used have been published online: see Hillmann et al. (2017). Any use of trade, firm, or product names is for descriptive purposes only and does not imply endorsement by the US Government. 


\section{LITERATURE CITED}

Bianchi TS, Allison MA (2009) Large-river delta-front estuaries as natural 'recorders' of global environmental change. Proc Natl Acad Sci USA 106:8085-8092

Borgnis E, Boyer KE (2016) Salinity tolerance and competition drive distributions of native and invasive submerged aquatic vegetation in the upper San Francisco estuary. Estuaries Coasts 39:707-717

Carter J, Merino JH, Merino SL (2009) Mesohaline submerged aquatic vegetation survey along the U.S. Gulf of Mexico Coast, 2000: a stratified random approach. Gulf Mex Sci 27:1-8

Chabreck RH (1972) Vegetation, water and soil characteristics of the Louisiana coastal region. LSU Agricultural Experiment Station Reports. Baton Rouge, LA

* Cho HJ, Biber PD (2016) Habitat characterization for submerged and floating-leaved aquatic vegetation in coastal river deltas of Mississippi and Alabama. Southeast Geogr 56:454-472

Cho HJ, Poirrier MA (2005a) Seasonal growth and reproduction of Ruppia maritima L. s.l. in Lake Pontchartrain, Louisiana, USA. Aquat Bot 81:37-49

Cho HJ, Poirrier MA (2005b) Response of submersed aquatic vegetation (SAV) in Lake Pontchartrain, Louisiana to the 1997-2001 El Niño southern oscillation shifts. Estuaries 28:215-225

Chrysoula C, Papastergiadou ES (2007) Spatial and temporal variations of aquatic macrophytes and water quality in six coastal lagoons of western Greece. Belg J Bot 140:39-50

Correia MJ, Costa JL, Chainho P, Felix PM and others (2012) Inter-annual variations of macrobenthic communities over three decades in a land-locked coastal lagoon (Santo André, SW Portugal). Estuar Coast Shelf Sci 110: 168-175

Couvillion BR, Beck H, Schoolmaster D, Fischer M (2017) Land area change in coastal Louisiana 1932 to 2016. U.S. Geological Survey Scientific Investigations Map 3381. https://pubs.usgs.gov/sim/3381/sim3381_pamphlet.pdf

CPRA (Coastal Protection and Restoration Authority) (2017) Louisiana's Comprehensive Master Plan for a Sustainable Coast. Coastal Protection and Restoration Authority of Louisiana, Baton Rouge, LA

DeMarco K, Couvillion B, Brown S, La Peyre M (2018) Submerged aquatic vegetation mapping in coastal Louisiana through development of a spatial likelihood occurrence (SLOO) model. Aquat Bot 151:87-97

Dennison WC, Orth RJ, Moore KA, Stevenson JC and others (1993) Assessing water quality with submersed aquatic vegetation: habitat requirements as barometers of Cheapeake Bay health. BioScience, 43(2): 86-94

* Doering PH, Chamberlain RH, McMunigal JM (2001) Effects of simulated saltwater intrusions on the growth and survival of wild celery, Vallisnaria americana, from the Caloosahatchee Estuary (South Florida). Estuaries 24:894-903

*Daarte CM (1991) Seagrass depth limits. Aquat Bot 40(4):363-377

Dunton KH (1990) Production ecology of Ruppia maritima L. s. l. and Halodule wrightii Aschers, in two subtropical estuaries. J Exp Mar Biol Ecol 194:107-131

Dunton KH (1994) Seasonal growth and biomass of the subtropical seagrass Halodule wrightii in relation to continuous measurements of underwater irradiance. Mar Biol 120:479-489
Dunton KH (1996) Photosynthetic production and biomass of the subtropical seagrass Halodule wrightii along an estuarine gradient. Estuaries 19:436-447

Flores-Verdugo FJ, Day JW Jr, Mee L, Briseno-Duenias R (1988) Phytoplankton production and seasonal biomass variation of seagrass, Ruppia maritima L., in a tropical Mexican lagoon with an ephemeral inlet. Estuaries 11: $51-56$

Fourqurean JW, Willsie A, Rose CD, Rutten LM (2001) Spatial and temporal pattern in seagrass community composition and productivity in south Florida. Mar Biol 138: 341-354

Frankovich TA, Morrison D, Fourqurean JW (2011) Benthic macrophyte distribution and abundance in estuarine mangrove lakes and estuaries: relationships to environmental variables. Estuar Coast 34:20-31

Frazer TK, Notestein SK, Jacoby CA, Littles CJ, Keller SR, Swett RA (2006) Effects of storm-induced salinity changes on submersed aquatic vegetation in Kings Bay, Florida. Estuar Coast 29:943-953

Gleason HA, Cronquist A (1991) Manual of vascular plants of northeastern United States and adjacent Canada, $2^{\text {nd }}$ edn. The New York Botanical Garden, New York, NY

Grime JP (1979) Plant strategies and vegetation processes. John Wiley and Sons, London

*Harrison PG (1982) Seasonal and year to year variations in mixed intertidal populations of Zostera japonica Aschers. and Graebn and Ruppia maritima L. S. L. Aquat Bot 14: 357-371

* Heiri O, Lotte AF, Lemcke G (2001) Loss on ignition as a method for estimating organic and carbonate content in sediments: reproducibility and comparability of results. J Paleolimnol 25:101-110

Hillmann ER, DeMarco KE, La Peyre M (2016) Establishing a baseline of estuarine submerged aquatic vegetation resources across salinity zones within coastal areas of the northern Gulf of Mexico. J Southeast Assoc Fish Wildl Agencies 3:25-32

* Hillmann ER, DeMarco KE, La Peyre MK (2017) Submerged aquatic vegetation and environmental data along a salinity gradient in Barataria Bay, Louisiana (2015). https: //www.sciencebase.gov/catalog/item/5a78ce8ce4b00f54 eb1e84d3 (data archive)

Horne JK, Schneider DC (1995) Spatial variance in ecology. Oikos 74:18-26

* Howarth RW, Teal JM (1979) Sulfate reduction in New England salt marsh. Limnol Oceanogr 24:999-1013

Joanen T, Glasgow LL (1965) Factors influencing the establishment of widgeon grass stands in Louisiana. Southeastern Association Game and Fish Commission. 19:78-92

Keim BD, Fontenot R, Tebaldi C, Shankman D (2011) Hydroclimatology of the U.S. Gulf Coast under global climate change scenarios. Phys Geogr 32:561-582

Kemp WM, Batleson R, Bergstrom P, Carter V and others (2004) Habitat requirements for submerged aquatic vegetation in Chesapeake Bay: water quality, light regime, and physical-chemical factors. Estuaries 27:363-377

Koch EW (2001) Beyond light: physical, geological, and geochemical parameters as possible submersed aquatic vegetation habitat requirements. Estuaries 24:1-17

*La Peyre MK, Rowe S (2003) Effects of salinity changes on growth of Ruppia maritima L. Aquat Bot 77:235-241

Langeland KA (1996) Hydrilla verticillata (L.F.) Royle (Hydrocharitaceae), the perfect aquatic weed. Castanea 61:293-304 
Lirman D, Deangelo G, Serafy J, Hazra A and others (2008) Seasonal changes in the abundance and distribution of submerged aquatic vegetation in a highly managed coastal lagoon. Hydrobiologia 596:105-120

Martin AC, Uhler FM (1939) Food of game ducks in the United States and Canada. Tech Bull 634. U.S. Department of Agriculture, Washington, DC

Merino JH, Nyman JA, Michot T (2005) Effects of season and marsh management on submerged aquatic vegetation in coastal Louisiana brackish marsh ponds. Ecol Restor 23:235-243

Merino JH, Carter J, Merino SL (2009) Mesohaline submerged aquatic vegetation survey along the U.S. Gulf of Mexico coast, 2001 and 2002: a salinity gradient approach. Gulf Mex Sci 27:9-20

Mishra S, Srivastava S, Tripathi RD, Kumar R, Seth CS, Gupta DK (2006) Lead detoxification by coontail (Ceratophyllum demersum L.) involves induction of phyto chelatins and antioxidant system in response to its accumulation. Chemosphere 65:1027-1039

NOAA (2019) National Climate Report-June 2019. https:// www.ncdc.noaa.gov/sotc/national/201906/supplemental/ page-3 (accessed 14 July 2019)

*orth RJ, Moore KA (1988) Distribution of Zostera marina L. and Ruppia maritima L. sensu lato along depth gradients in the lower Chesapeake Bay, USA. Aquat Bot 32:291-305

Patrick CJ, Weller DE (2015) Interannual variation in submerged aquatic vegetation and its relationship to water quality in subestuaries of Chesapeake Bay. Mar Ecol Prog Ser 537:121-135

Patrick CJ, Weller DE, Orth RJ, Wilcox DJ, Hannam MP (2018) Land use and salinity drive changes in SAV abundance and community composition. Estuar Coast 41: 85-100

Penfound WT, Hathaway ES (1938) Plant communities in the marshlands of southeastern Louisiana. Ecol Monogr 8:1-56

Peyronnin N, Green M, Parsons Richards C, Owens A and others (2013) Louisiana's 2012 Coastal Master Plan:

Editorial responsibility: Brant Touchette, Elon, North Carolina, USA overview of a science-based and publicly informed decision-making process. J Coast Res 67:1-15

*Pickett STA, Cadenasso ML (1995) Landscape ecology: spatial heterogeneity in ecological systems. Science 269: 331-334

Pulich WM (1985) Seasonal growth dynamics of Ruppia maritima Lsl and Halodule wrightii Aschers. in southern Texas and evaluation of sediment fertility status. Aquat Bot 23:53-66

SAS Institute (2010) SAS user's guide: statistics. SAS Institute, Cary, NC

Smith CS, Barko JW (1990) Ecology of Eurasian watermilfoil. J Aquat Plant Manag 28(2):55-64

* Snedden GA, Steyer GD (2013) Predictive occurrence models for coastal wetland plant communities: delineating hydrologic response surfaces with multinomial logistic regression. Estuar Coast Shelf Sci 118:11-23

Strazisar T, Koch MS, Madden CJ (2015) Seagrass (Ruppia maritima L.) life history transitions in response to salinity dynamics along the Everglades-Florida Bay ecotone. Estuar Coast 38:337-352

ter Braak CJF, Smilauer P (2002) CANOCO reference manual and CanoDraw for Windows user's guide: software for canonical community ordination (vers. 4.5). Microcomputers Publishing, Ithaca, NY

Visser JM, Duke-Sylvester SM, Carter J, Broussard WP III (2013) A computer model to forecast wetland vegetation changes resulting from restoration and protection in coastal Louisiana. J Coast Res 67:51-59

Weiher E, Keddy PA (1995) The assembly of experimental wetland plant communities. Oikos 73:323-335

Wiens JA (2000) Ecological heterogeneity: an ontogeny of concepts and approaches. In: Hutchin MJ, John EA, Stewart AJA (eds) The ecological consequences of heterogeneity. Blackwell Science, Oxford, p 9-31

*Wilkinson RE (1963) Effects of light intensity and temperature on the growth of waterstargrass, coontail, and duckweed. Weeds 11:287-290

Submitted: March 26, 2019; Accepted: August 29, 2019 Proofs received from author(s): November 13, 2019 